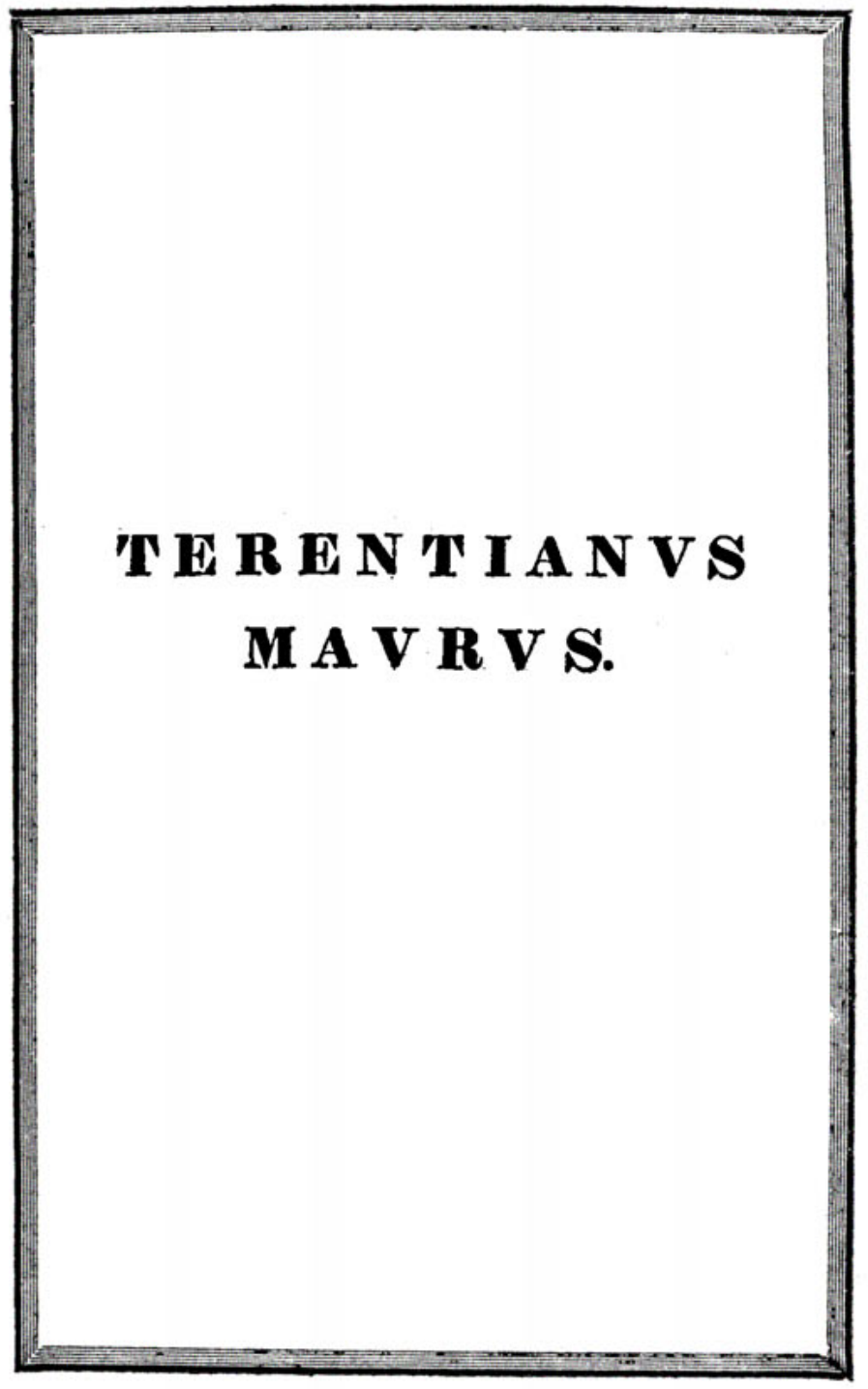





\section{TERENTIANI MAVRI}

DE LITTERIS SYLLABIS ET METRIS LIBER

RECENSVIT

CAROLVS LACHMANNVS.

BER OLINI

TYPIS ET IMPENSIS GE. REIMERI

A. 1836. 
